Contact authors at:

René Wintjes

MERIT, University Maastricht,

Postbus 616, 6200 MD Maastricht

Tel: (31) (0) 43-3883893

R.Wintjes@Merit.unimaas.nl

\title{
Knowledge intensive Industrial Clustering around Océ; Embedding a vertical disintegrating codification process into the Eindhoven-Venlo region 1
}

\author{
René Wintjes \& Jan Cobbenhagen \\ MERIT, University of Maastricht \\ Postbus 616, 6200 MD Maastricht
}

Januari 2000

\begin{abstract}
This case study provides insight into how a particular transformation of the innovation process affects individual companies and the regional Mechatronics system as a whole in the Eindhoven-Venlo region (The Netherlands). The transformation involves out-sourcing engineering activities by Océ, one of the major high-tech companies in the region. Océ wanted to upgrade regional suppliers from 'jobbers' into 'main-suppliers' so that most of the engineering could be done by suppliers while Océ played the role of system integrator. Local suppliers saw an opportunity to reduce the extent of (production) cost competition by increasing their own innovative competences. Under the Knowledge-intensive Industrial Clustering (KIC) policy programme the collective goal is to build up internal knowledge resources and increase the use of external knowledge resources in the local area. The case study shows that the change in allocation between internal and external knowledge resources is not
\end{abstract}

\footnotetext{
1 This study is part of the European Union T.S.E.R. project "Industrial districts and localised technological knowledge" (INLOCO). We thank Robin Cowan and Claire Nauwelaers and those attending the Nice Seminar of the INLOCO research group for comments on a previous version of this paper.
} 
an easy (costless) change. The restructuring of a codification process requires intensive communicative interaction between heterogeneous knowledge resources and this is favoured by proximity.

\section{Introduction}

In 1994 Océ, a high-tech multinational making specialised copy mashines, and the regional Innovation Centre initiated the Knowledge-intensive Industrial Clustering (KIC) programme. As a joint public and private policy including Océ, regional suppliers, regional innovation support organisations and governments, the KIC programme aims at localising and embedding Océ's codifying process into the region in order to take advantage of the externalities stemming from this codifying process. As a policy instrument it is designed to re-arrange the regional innovation system by supporting regional suppliers to generate, absorb and cultivate technological externalities that stem from Océ's strategy to out-source engineering activities. The R\&D and Purchasing units of Océ, the subsidising authorities and the regional suppliers all play a decisive role in this transformation.

In the Eindhoven-Venlo region, approximately 40 firms are engaged in one or more of the 20 micro-clusters. In a typical KIC project a multi-disciplinary micro-cluster of 3 to 4 suppliers from the region work together, co-engineering a labmodel of a module into a manufacturable one. A typical KIC firm is a small or medium-sized skill-intensive firm, whose innovative capacity traditionally consists of tacit knowledge accumulated by many years of internal learning from experience. Firms are in a variety of industries: metal processing, electronics, plastics processing, glass, ceramic, software or plating. Out-sourcing these engineering activities means that firms are externalising a non-strategic part of their codifying process.

We claim in this case study that the change in allocation between internal and external knowledge resources is not an easy (costless) change. The restructuring of a codification process (internalising and externalising, integrating and dis-integrating) requires intensive communicative interaction between heterogeneous knowledge resources. Proximity is helpful in this respect. The KIC programme is a 'learning to innovate programme'. By 'doing', the firms build up codifying and de-codifying capabilities, learn how to exchange tacit knowledge and learn how to reorganise their internal innovation processes accordingly. The collective goal is to build up internal knowledge resources and increase the use of external knowledge resources in 
the local area. In doing so the firms: "adapt to each other and influence each other towards adoption" (Johanson \& Mattson 1991: 257).

After discussing mechatronics in the Eindhoven Venlo region as the regional and sectoral context, we will take a closer look at Océ and its out-sourcing strategy. Based on secondary data and twelve in-depth interviews, the changing innovation process of firms in the KIC programme will also be analysed.

\section{Mechatronics in the Eindhoven-Venlo region}

The Eindhoven-Venlo region is, in many ways, the most flourishing manufacturing region in the Netherlands. Over 2,5 billion NLG (roughly one half of total Dutch spending on R\&D) is spent annually on R\&D in the region. This places the area next to Paris and Munchen/Neurenberg as one of the most knowledge-intensive industrial areas in Europe. Several sectoral clusters of firms and institutes can be identified. Taken together the core industry in the region can be classified as Mechatronics.

Traditionally, trade, logistic and other services have always dominated the Netherlands economy, in preference to manufacturing. Eindhoven-Venlo has a high level of industrialisation by Dutch standards: 29 percent of its labour force is in manufacturing, whereas the national average is only 18 percent. The Dutch manufacturing industry as a whole is dominated by capital-intensive process-industries like bulk chemicals and food industries, whereas Eindhoven-Venlo is more specialised in industries like electronics, machinery and metals. Everywhere in the Eindhoven region one can sense the presence of Philips. In North Limburg, office machines dominate with Océ in Venlo and Rank Xerox in Venray.

The strong de-industrialisation in The Netherlands during the 1970s and 80s had a negative impact on the Eindhoven-Venlo region. The region is therefore now supported by European funds. $^{2}$ Ten years ago the region faced serious decreases in employment in manufacturing industries. Big companies like Philips, DAF and NedCar cut back drastically in employment. Although total regional employment between 1990 and 1994 increased 4 percent annually, this was far below the national 12 percent. In recent years, however, there has been a recovery, partly due to a revival of manufacturing industries.

2 South-east-Brabant as objective 2 region and North- and Central-Limburg as objective $5 \mathrm{~b}$ region. 
Several recent studies (Meeus \& Oerlemans, 1995; Louter \& Smits, 1997; KPMG, 1996) using a variety of indicators identify the Eindhoven-Venlo region as a one of high innovative capacity in manufacturing, and also a region with a high level of internal coherence due to a concentration of traded and untraded interdependencies. By using an input-output methodology, indicating traded interdependencies, the NEI (1996) identified eight 'clusters' of firms and institutions in the Eindhoven-Venlo region:

- Mechatronics;

- Electronics;

- Automotive;

- Office-machines;

- Transport/value added logistics;

- Environmental technology;

- Medical technology;

- Agribusiness.

Several of these clusters are strongly related and overlap; more than 20 percent of the firms identified by NEI operate in more than one cluster. Since mechatronics refers to the (early) integration of electronic, mechanical and information technology, it links together the electronics, office-machines, automotive and transport/value added logistics cluster (see figure 1). Of the 400 most important firms and technological institutions in the region (together employing 57.000 people) more than half (with 43.000 employees) were in the 'mechatronics cluster'.

The knowledge infrastructure is represented by 14 (public, public/private and private) technological institutes that employ some 4.000 people. This public/private knowledge infrastructure is dominated by the Technical University Eindhoven and the higher vocational training institutes in Eindhoven and Venlo. ${ }^{3}$ Some of the other technological institutes are TNO, Innovation Centra and the Centre for Construction and Mechatronics. The prime private basic research labs are Philips' Natlab (2000 employees) in Eindhoven and Océ (1200 employees) in Venlo. Together Philips' and Océ's R\&D expenditure in the region comprises an estimated three quarters of the total $R \& D$ expenditure in the region.

3 The first engineer graduated in Mechatronic Engineering at the TUE in 1994. 


\section{[Insert here] \\ [Figure 1 Industrial knowledge-clusters in the Eindhoven-Venlo region]}

Another way to identify clusters is by analysing patent citations indicating 'pure' knowledge spillovers. Verspagen (1998: 21) has identified that "there are a very limited number of local (i.e., Dutch) firms which benefit from Philips spillovers, or which 'supply' spillovers to Philips". The scientific network, however, seems to have some Dutch component, but the effect is still relatively small. Interviews informally indicate that the geographical pattern of these 'pure' knowledge spillovers to and from Océ resembles that of Philips, although Dutch Universities (outside the region) seem to play a larger role in the scientific network of Océ than they do in that of Philips. Others (e.g. Oerlemans, 1996), have claimed the importance in the region of 'impure' knowledge spillovers stemming from user-producer interaction in local innovative networks.

Two main trends can be identified for the manufacturing industries in the Eindhoven-Venlo region. First, there is a shift from a mono-disciplinary to a multi-disciplinary creation and application of knowledge. Mechatronics is an important result of this trend. The changing inputoutput structure and the changing position of subcontractors due to vertical disintegration is the second trend. Subcontractors have to transform from traditional 'jobbers' into 'co-makers' and 'co-engineers' by increasing their innovative capacity and organisational skills. Both of these trends are transforming the region as an innovation system, which can be illustrated by analysing the KIC-programme at the core of both transformation processes.

\section{$3 \quad$ Océ and its out-sourcing strategy}

Océ operates in a science-based industry that is dominated by Japanese and American companies. Out of the 18.000 employees world-wide, approximately 3.500 work in Venlo where the headquarters, assembly and $\mathrm{R} \& \mathrm{D}$ are located. Total $\mathrm{R} \& \mathrm{D}$ manpower is 1.500 , mostly concentrated in Venlo.

Océ was founded in 1877 in Venlo, and took its first steps in the copying business in 1920. Océ now supplies a wide range of products and services for the presentation, reproduction and distribution of information on paper, like wide format copy machines for the engineering market. With its first self-developed printers in 1986 and the introduction of its first fully digital 
copier/printers in 1994, Océ joined the Information Technology (IT) sector. Within a short time digitisation started to play a decisive role in all levels of the organisation. Today electronics and software have become the prime disciplines in Océ's research and development (see figure 2). Currently 40 percent of Océ's sales relate to digital products, and this development is reflected by the fact that the IT magazine 'Datamation' now ranks Océ amongst the world's top 100 IT businesses.

Although electronics and software have become the most important disciplines in Océ's research and development-unit, Océ's internal codification process remains multi-disciplinary as the creation of new technological knowledge concerns an 'early' integration of several technological fields (see figure 2). Moreover, 75 percent of the $R \& D$ budget is spent on multi-disciplinary projects, using both internal and external knowledge resources in development and engineering, whereas 25 percent is spent on mono-disciplinary, basic research. R\&D activities are vital to Océ's position in the high-end markets. Over the last ten years the budget for R\&D more than doubled from 124 million NGL in 1987 to 305 million in 1997. One of Océ's most recent inventions is a new colour copy technology. Especially the early KIC projects are set up to engineer systems or modules for this new colour copier.

\section{[Insert here]}

[Figure 2 Discipline ratio for Research and Development at Océ in number of employees, 1980-2000]

For Océ out-sourcing is not a recent phenomenon. Océ is a 'head-tail' company, focused on R\&D, assembly and after-sales. As a 'system-integrator', manufacturing or production technology has never been Océ's core technological competence; copying and printing technology is. Océ buys 90 percent of all parts and components, equal in value to 85 percent of total sales, from other companies. Besides out-sourcing manufacturing activities Océ now also wants to out-source engineering. This way Océ can remain focused on product development and at the same time gain freedom in design and choice of technology. Since "the integration of resources [...] creates irreversibilities which may become obstacles to change" (Foray 1991: 397): dis-integration reduces irreversibilities. It may increase the range of technological choices available to the out-sourcing firm. 
Océ's out-sourcing strategy is based on the supposition that, in the long run, it is best (in terms of cost, time, and quality) to let subcontractors do part of the engineering. This trend has already changed the entire automobile industry, and for several years now Océ has been applying this concept to the Office Machines industry. Before the Innovation Centre in Venlo persuaded Océ to apply the KIC-concept, Océ applied a strategy called Early Supplier Involvement (ESI). Océ transformed its innovation process from a linear model towards a more interactive one where the separate but complementary phases, from basic feasibility studies to market introduction, were more or less integrated and overlapping each other. Thus, the development phase started before the basic research phase had ended and engineering started before the development of a labmodel had ended. This implied that suppliers be involved in engineering before they started to produce components.

Historically, 'jobbers' were used to following strict orders. Typical to the Fordist mode of production and the linear approach to the innovation process, jobbers produced according to detailed instructions, and they were not supposed to 'think' for themselves. The exchange was co-ordinated by the principals of 'market' and 'hierarchy', as Océ mainly communicated through price and authority (Powell, 1990). However, with the introduction of the ESI strategy, Océ had started to involve suppliers in the engineering process in a one-on-one relationship. With the KIC programme Océ takes it a step further by sourcing most of the engineering out to a group of co-operating suppliers in the region.

\section{[Insert here]}

[Figure 3 Origin of Océ's purchases, geographical distribution, in $\operatorname{mln}$. NGL for 1988, 1993, 1996]

A few years ago Océ put a lot of pressure on their regional suppliers, threatening to go to East European suppliers if they did not invest in human resources and develop innovative capabilities. If the suppliers in the region did not succeed in upgrading their firms from 'jobbers' to 'comakers' Océ would turn to 'global sourcing' as the best alternative ${ }^{4}$. Suppliers from the region seemed able to compete with more remote firms in Eastern Europe or the Far East (see figure3). 
Océ in fact discovered that working with East European subcontractors did not bring the success they had expected. They had underestimated the transaction-costs and especially the 'costs' of communication. It was not the physical distance or transportation costs that made it difficult to involve subcontractors into the innovation process, but the 'costs' of covering technological, cultural and institutional distances. Therefore, as far as the R\&D department was concerned, outsourcing engineering to East European firms was not advantageous. Interestingly, the purchasing department thought that out-sourcing to the east was successful since the difficulties of the R\&D department in communicating knowledge and innovation are not quantified as 'costs', and are not incorporated in the prices the purchasing department has to pay for. This could explain why the purchasing department is less enthusiastic about regional suppliers and the KIC-programme than are people from $R \& D$.

\section{The KIC-programme}

The KIC programme was established in 1994 as a public-private policy-instrument to promote innovative clustering or networking among firms within the region by upgrading the innovative capabilities of regional SME suppliers. From its inception, the KIC project has been an influential example for many other cluster-policy-projects and at present the KIC-concept will be integrated into Dutch cluster-policy (Roelandt et al., 1997; Ministerie voor Economische Zaken, 1999). By creating co-operative structures which promote interactive learning within the region, SMEs get the opportunity to prove and improve their competence in co-development and engineering, and to learn from other firms in the micro-clusters. 5

The main idea originates from the regional Innovation Centre (IC) in Venlo (which more recently goes by the name of Syntens). The basic concept was based on a former experience with the formation of a regional micro-cluster of three firms which successfully co-operated in engineering. The Innovation Centre wanted to use the experience from this pilot-project to promote innovative linkages between the co-located small firms in the region, and at the same time bridge the gap between the few very large and the many small firms. One of the members on the board of the IC in Venlo 'happened' to be the director of Océ's R\&D business-unit. The IC managed to persuade the R\&D top management and the chairman of the board of directors to join them in setting up the Knowledge-intensive Industrial Cluster-programme (Dirix, 1998). In

5 Many aspects of the project have been changed over the years. See Nauwelaers et al. (1999) for an evaluation of KIC as a policy-instrument. 
1995 several institutions officially signed the KIC agreement 6 . The original KIC-budget was 71 million NGL for three years. The European Union, the Dutch ministry of economic affairs and the provinces of Brabant and Limburg provided 24 million NGL. The rest of the funds came mostly from the participating firms (mainly Océ).

The idea was to form micro-clusters of a few firms, and to give them the opportunity to engineer a lab-model of a new part or module for Océ's new colour copier into a manufacturable one. Out of the KIC-budget the KIC companies received a subsidy of 37.5 percent of their development costs. The KIC clusters were organised in order to translate lab-models into products that could be manufactured at costs considerably lower than Océ would otherwise have had to pay. Like the Early Supplier Involvement strategy of Océ, the KIC programme is based on the advantages of early collaboration in multi-disciplinary clusters. Besides engineering capabilities, this also requires new organisational structures and communication skills which are vital for any firm wishing to become a 'main-supplier'.

During 1994 the first KIC clusters were established. In the beginning Océ identified the modules to be developed by the clusters and IC consultants selected the firms. Under the supervision of the IC consultants the clusters started to co-engineer. Based on their experience in innovation support to small and medium-sized companies in the region, the IC consultants knew potential candidates. Most of these firms had been located in the region for several decades. As an IC manager of that time states: "We managed to persuade Océ of the competencies of these small regional firms and they appeared to have technological and organisational capabilities that Océ was not aware of."

The organisational flexibility based on the informal character of the co-operation among the small firms impressed the R\&D unit of Océ. As Océ became more and more convinced of the concept (helped by the attraction of funds) it gradually took over the organising role of the IC. At present, Océ not only identifies the modules to be developed by a cluster, but also selects and approaches the firms. According to the IC, "it is a sign of good public policy, when we can step back after initiating a development so private actors can continue it." In 1996 the IC officially withdrew from the program because of a disagreement with Océ. Later, half of the public budget was withdrawn, because the target of 100 micro-clusters had not been met and because KIC still

\footnotetext{
6 Océ Nederland BV, Innovation Centers of North and Mid-Limburg,Oost-Brabant, Zuid-Limburg, povincial government of North-Brabant and Limburg, the NV Industriebank Liof, the BOM (Brabantse Development Agency), the regional labour offices and the Limburg Chamber of Commerce.
} 
involved only one 'lead-firm', while the involved governments had stressed the importance to let other out-sourcing 'lead-firms' in.

\section{$5 \quad$ Problems and progress}

Although the IC did not leave the scene entirely (it supported several KIC firms with the regular generic policy-tools for innovation in SMEs) some elements of the KIC project as a policy-tool gradually received less attention. More and more Océ selected firms it already knew, not searching for less obvious ones. This meant that fewer new communication channels between Océ and SME suppliers in the region were created. More and more, KIC was used to strengthen and up-grade the existing links with existing Océ suppliers. Also, as several KIC firms have stated, the teaching element originally proposed by the IC was never implemented. The involvement of professional engineering consultants in the clusters was meant to supply this teaching-element, but these engineering bureaus were by-passed in the formation of the later clusters. Suppliers taught themselves how to acquire development and engineering skills, and they taught themselves how to co-operate with each other simply by 'doing'. As most of the interviewed firms have stated they would not have liked to have it any other way, since they are accustomed to learning-by-doing and moreover they seem to be doing it well.

Another problem concerned the lack of contract guarantees for KIC firms to actually produce the modules that they had engineered. In contrast to several other cluster-programmes which have been initiated under the Stimulus Programme 7 , a KIC project ends when the engineering is completed successfully and the drawings and proto-types are handed over to Océ. Thus, participating in a KIC project does not guarantee that the KIC companies will be contracted to actually (mass-) produce the module they engineered. This frustrated the KIC firms in some clusters. Most firms, however, highly appreciate the learning effects, even if they do not get the actual contract to produce the module. Getting the production contract is not the main reason for participating in the KIC scheme, rather the emphasis is on upgrading their innovative capabilities.

A related issue concerns ownership of the created knowledge in KIC projects. Several interviewed firms mentioned that all the codified knowledge resulting from a project officially

7 Objective 2 funded regional revitalisation programme in South-east North Brabant (NV. REDE, 1996). 
belongs to Océ, e.g. potential patents. However, as stated in the detailed KIC-handgide ${ }^{8}$ a clustermember may patent process-technologies, but Océ may not be excluded. Dealing with intellectual property rights, however, does not seem to be a serious problem. First of all, the products are highly client-specific. The suppliers are actually not specialised in products but in processes, and none of them supplies exclusively to the copy-machine industry. Only one of the interviewed firms suggested that they could use the product-design in serving another client. Secondly, due to the small size of firms, they lack the power to resist potentially interested larger firms, and, moreover there is a lack of scale to obtain a proper return on costly patenting procedures. Thirdly, the suppliers lack a patenting tradition. They have a tradition to stock and hide knowledge in a tacit form, accumulated in the skills and experience of their employees. Although KIC has enhanced their codifying capabilities, most firms do not see the need of patenting.

A problem of a different type concerned the exchange of CAD-data: the co-operating suppliers used different CAD-systems. Standardising on one system was not the answer since other customers of the suppliers still used different systems. Océ and Philips launched the ASCIIproject to tackle this problem, by increasing the compatibility between the different systems.

An additional complicating factor in finalising the (production) contracts with the clustering firms was the fact that Océ had to delay the production start-up of their new colour copier due to some problems with the totally new and leading edge technologies. We can use this, however, to illustrate one of the strengths of the KIC approach. Had the KIC firms been heavily dependant on contracts from Océ, the delay would have caused severe problems for them. This refers to the danger for suppliers of getting 'locked-in' to the technological trajectory of a client on whom they depend heavily. It also illustrates 'the strength of weak ties' (Granovetter, 1973), since none of the KIC firms depends solely on contracts for this new colour copier, or Océ, or even the office machine industry. The KIC firms are specialised in process-technology and the material they use. They develop skills in mechatronic engineering and not in a specific product or product-based sub-sector. This is also typical of the dynamic strength of the Eindhoven-Venlo region as a whole. As the relatively small regional-economic impact of former troubles at principal out-sourcing firms like DAF and Philips has shown, the regional production system has a high internal flexibility. Unlike the Fordist regime, or the hierarchical, pyramid shaped, strongly interdependent supply structures the Japanese are so famous for, the supplier-base survives if a core firm fails to do so. So at different levels, whether within KIC firms, within 
KIC clusters or within the Mechatronics cluster in the region as a whole, the internal and external economies of scope, 'the strength of weak ties' or Jacob's-like externalities prevent firms from being 'locked-in' to an irreversible dead-end trajectory induced by one of the core firms. At the same time these suppliers which serve several sectors (recall figure 1) fulfil an important role in the 'spill-overs' between sectors, due to their relationships with 'end-producers' in several sectors. The average origin of external knowledge as estimated by the interviewed KIC-firms supports this, since 10 percent of the external knowledge used for product- and processinnovations stems from the cluster and almost 40 percent stems from other sources in the region.

The KIC-programme can best be characterised as a learning and transformation process. While Océ originally stressed the need for suppliers to learn how to become 'co-makers' or 'mainsuppliers', it appears that Océ itself had -and still has- a lot to learn. First of all, Océ's R\&D-unit had to learn how to relate to suppliers as external sources of knowledge. Both Océ's R\&D-unit and the KIC firms refer to considerable progress that has been made since the KIC programme was initiated, which will pay off in future projects. On the other hand, both Océ's purchasing unit and most of the KIC firms are still not too enthusiastic about their relationship. Océ's purchasing unit wants to see 'ex-post' results in terms of low final production costs, and also emphasises the need to externalise 'chain-management'. The purchasing unit also has a different view on the opportunities in Eastern Europe and the importance of proximity in general, since, according to the interviewed Purchasing Manager: "the most complex modules come from Japan”. This reflects what may be referred to as Océ's second organisational learning process.

Océ had to reorganise internally in order to co-ordinate the ('forward and backward') externalisation of activities of both the R\&D unit and the purchasing unit. Recalling the 'headtail' character of Océ, we can place the communication problems mentioned by the KIC-firms and Océ (see figure 4). Especially concerning the early clusters, suppliers claimed to be 'stuck in the middle' between Océ's R\&D department and the Purchasing-unit (sub-unit of the Manufacturing and Logistics (M\&L) department). In the first clusterprojects 'R\&D' and 'Purchasing' communicated with the suppliers in separate meetings. Later both Océ's 'head' and 'tail' were represented in these meetings. Besides better communication and co-ordination between the involved departments of Océ, an other solution to the problem of 'integrating' engineering and production concerns externalising the management of the supply-chain to several 'main-suppliers'. Therefor, at present Océ is thinking of 'training' several KIC-firms in becoming 'main-suppliers'. These suppliers may keep on co-engineering with their former KICpartners, and when it comes down to mass-production they may organise the outsourcing themselves, i.e. taking the 'cluster drawings and prototypes' to East-Europe. 
In fact the decreasing number of participating firms per micro-cluster already indicates this trend of externalising whole parts of the value-chain and leave the chain-management to one firm in the KIC clusters.

\author{
[Insert here]
}

[Figure 4 The position of KIC-clusters in between Océ's $R \& D$-unit and assembly plant]

\title{
$6 \quad$ KIC firms and -clusters: transforming the innovation process
}

The KIC programme has evolved over its lifetime as structural difficulties with original arrangements have come to light. The role of the engineering consultants has been diminished, and the (formal) size of the clusters has fallen. Nonetheless, the original aim of increasing the innovative capacity of supplying firms has improved dramatically. This has been accompanied by overall growth of those firms. At the end of this section we introduce two firms to illustrate this transformation process.

During a KIC project the KIC firms learn to learn. They learn how to produce, use and communicate knowledge. The efficiency of the management of KIC as a policy-tool can be questioned, but according to the impact observed by the KIC firms and Océ's R\&D-department, it is a very effective policy-tool. Whether initiating or speeding up the transformation process, all the KIC companies agree that the KIC project helped to increase their innovative capabilities. Besides the increase in internal competences, the firms learned how to combine their improvements with the internal competences of their co-engineering partners. In several cases the KIC clusters used the 'joint, new competence' that was built up during their project for Océ in other co-engineering projects. Most of the firms and clusters have not (yet) gotten a contract to produce and supply the products they engineered for Océ, but they learned a lot in the process.

The codified knowledge output created in the projects is hardly of any use to the KIC firms or clusters in relation to other clients, and to a large extent Océ does not allow them to use it, stock it, or sell it to non-clustermembers. Thus, apart from process-technology, patenting is not an option. Neither is selling the drawings or the engineered products to other office machine manufacturers. Moreover, since participating in a KIC cluster does not guarantee a contract from 
Océ to supply the product, KIC does not refer to tradable interdependencies, nor to static efficiency. It refers to dynamic efficiency and collective learning capabilities which are based on untradable interdependencies (Storper \& Salais, 1997). Furthermore, KIC does not refer to the codified knowledge output, but to the creation of knowledge resources (Aoki, 1986; Håkansson, 1993) and the transformation of the codification process (Cowan \& Foray, 1997).

As most KIC participants can be classified as former jobbers, they did not have much engineering capability. They were already able to read highly specified technical drawings, and they knew how to translate them accurately into products. Most of all they knew how to produce them at low cost. The drawings or specifications were never questioned, since their clients were supposed to know best and 'the client's wish was the jobber's command'. In a KIC project these firms had to improve the drawings that were made by Océ and they had to communicate the functionality of the specifications with researchers from Océ. This implied a big social and cultural change. As one manager put it: "Our people were not used to asking questions and they were not keen on trying to convince people from Océ's R\&D lab they had a better solution." Likewise, people from Océ's R\&D-lab were not used to communicating with suppliers, and according to some suppliers it took a while before they could imagine that a cluster of small regional suppliers could come up with good designs or even better solutions.

Over the course of the KIC programme, the nature of clusters has evolved. In total there are approximately $40 \mathrm{KIC}$ firms that have participated or still participate in one or two of the 20 micro-clusters. In the early projects, clusters were formed by an average of 4 to 5 firms. The clusters have become smaller. In these early clusters an engineering consultant was often one of the participants. Océ, however, did not want the consulting firms to take over leadership of the clusters. According to the interviewed R\&D manager of Océ, the engineering consultants have the same kind of scientific knowledge and codifying skills as engineers at Océ have: "It is the kind of knowledge that looks perfect on paper, but we explicitly wanted to make use of the skills of suppliers because it has been tested in practice and is built on years of experience".

Despite the advantages of the loose, informal, flexible organisation among the co-operating firms in the clusters, it became apparent that introducing some hierarchy and assigning one firm as the consortium leader worked best. However it does not have to be a rigid hierarchical structure. As two former KIC-partners explained their present relationship: "In some projects we asked them to take the lead and in other projects we were the co-ordinators and took the final responsibility". It also emphasises again the idea of suppliers learning how to take over part of the supply chain themselves in order to become a 'main-supplier' for Océ. 
After five years the KIC-programme has formally ended in 1998, but in 1999 the National government will present a 'follow-up'. In order to support the upgrading of other buyer-supplier networks as well the KIC format is now being redesigned into a national policy-tool. At least one former KIC-firm is expected to apply for this new policy-tool and take the lead in developing a supply-network itself.

In spite of the evolution in the nature of the clusters, the KIC firms have indeed undergone a transformation. They have grown rapidly, typically more than doubling in employment. Further, they have grown from almost zero to an average of 6 percent of their labour force being structurally engaged in R\&D.

By introducing two of the interviewed firms we illustrate the transformation process:

'Metal- $X^{9}$ was founded in 1954. Within the metals sector, Metal-X specialised in aluminium and fine-mechanics. Over the last ten years Metal-X has grown from 90 to 210 employees. The present organisational structure show signs of the regional and sectoral embeddedness, as one unit is specialised in making prototypes, one in fine-mechanical engineering, one in mechatronics, and another in roller-technology (for copying and graphic industries). In 1992 it also acquired a majority ownership in a Romanian company so it could make use of the labour cost differentials.

As a skill-based company most of Metal-X's internal knowledge originates from learning-bydoing. Only recently has Metal-X begun to keep a record of R\&D expenditures, largely to be eligible for R\&D subsidies. Three employees are structurally engaged in activities that may be labelled R\&D, for several others it is not their permanent or main activity. Metal-X's internal knowledge stems from years of experience in working with state of the art machinery. As other KIC firms have also mentioned, Metal-X stated: "We get more out of our machines than the original manufacturers thought possible." 'More' refers most of all to 'more precise'. A cleanroom facility adds up to the accuracy that is needed to supply clients like Airbus (Aerospace), ASML (chip-machinery) and Océ. "The knowledge we build up is a matter of trial and error and being alert, it's not a purposeful activity and even if we wanted to the result is often very difficult to patent." New engineers with a higher vocational training degree, handle the machines for half a year before he is permitted to engage in engineering. The tacit knowledge that is built up in

9 Anonymous, not authorized to use the firms name. 
employees through years of experience is vital to Metal-X. This also explains why it invests a lot in retaining employees e.g. a full time job includes only four working days a week. Metal-X is linked to the regional clusters of mechatronics, automotive, office machines and medical technology. It is also involved in two KIC clusters.

The KIC cluster with Glass-X, a specialist in glass, was one of the first KIC projects. The cluster had to solve a problem of attaching a glass cylinder to a metal-construction. $\mathrm{N}-\mathrm{X}$ and Engineering-X also took part in the project, but they played minor roles. The firms already knew each other vaguely, but co-operation in the KIC project has created a more structural relationship. Learning about each others' capabilities has opened up opportunities for co-operation in other projects. According to Metal-X: "physical as well as cultural proximity made it much easier to co-operate in engineering. Our business culture fits nicely with that of Glass-X, but it took a while before there was an 'open' communication with Océ's R\&D-unit. In the second KIC project the communication with Océ's R\&D-unit was much better". The relationship with Océ's purchasing department, however, has to be improved. Despite the fact that Metal-X still does not know if they will get the contract to supply Océ, the KIC projects have sped up the internal transformation process. It stimulated the firm to structure and expand its innovative capacity and most of all it gave it the chance to learn to co-operate in engineering, which will be vital in the future.

'GlasX' was founded in 1962 in a village near Eindhoven. Ten years after its founding it employed 5 and in 1985 employment was 75. The firm split in two and at present there are 50 employees at GlassX. It produces in small batches and the products are highly client-specific. At present engineering has become an important activity, next to the actual production. Before participating in the KIC project the firm knew that it had to become knowledge intensive, because it was neither able to compete on price nor to produce on a large scale. With KIC it learned how to co-operate in innovation with other firms and it has built up codifying capabilities: "We had to make research- and test-reports and we had to provide sound arguments for the engineering decisions we made. Our people had to put this all on paper but they were not used to it and lacked the skills to do it the way Océ expects us to do. This is why there are now many people working here who had worked for Philips once. Some of them worked at the Natlab [Philips basic R\&D centre in Eindhoven] and they are perfectly able to write the kind of reports we have to deliver with the requested drawings and products." GlassX also has contacts with several private and public R\&D-centres in the region but none of those contacts is formal. "We know these people personally and we do not call them during day time, otherwise we would have to pay large sums of money we can not afford." GlassX is at present one of the famous KIC 
stories and next to Océ it serves a diverse set of well-known innovative companies like ASML, Philips and Miele.

\section{Summary and conclusions; Linking skill-based industries to science-based industries within the region}

While Océ can be labelled as science-based, the regionally based KIC companies represent skillintensive industries. In multi-disciplinary Knowledge-intensive Industrial Clusters, firms use and socialise their tacit knowledge, built up by years of 'learning by doing', in order jointly to transform a prototype of a new product or module into a manufacturable one. By out-sourcing these engineering tasks, Océ externalises part of the codification process to the region. This way the externalities between the separated phases of the codification process are kept within the region. Moreover, these externalities are absorbed, accumulated and cultivated within the regional supplying firms and micro-clusters of firms. Especially the firms of the mechatronics 'sector' play an important role in socialising the technological externalities within the region, e.g. by supplying to other clusters or core firms in the region like Philips, Stork, DAF, Rank Xerox or ASML. So, the Eindhoven-Venlo region is a multiple-core district.

This case shows that when innovation is concerned, internal and external resources are not as perfectly substitutable as the transaction cost approach suggests. Externalising part of the codifying process by Océ's R\&D-unit to regional suppliers is not an easy 'make or buy' decision, which can be executed over night, as evidenced by the difficulties encountered in the attempt to turn to eastern Europe. And neither is internalising for the suppliers. Océ's R\&D-unit had to create new organisational structures (internal and external) and communicative capabilities to coordinate the complementarity of the development- and engineering process in another way. Since, co-operation exists whenever there is a need to co-ordinate non-similar but closelycomplementary activities (Foray, 1991), Océ's R\&D-unit chose the ex ante co-ordination of cooperation. It could not be left to the ex post co-ordination of the market, solely communicated through prise. Océ's R\&D-unit had to experiment and invest in building stable technological relationships with external resources. Communication channels had to be created and 'opened'. Meanwhile, they did not shut down their internal engineering unit, so, some duplication still exists. The 'cheap' alternative in Eastern Europe did not work very well; the costs of communication were too high. So Océ decided to develop external resources in the proximity of the region by 'helping' regional firms to build up an internal codification capacity in order to tap into their already existing stock of tacit knowledge. 
Accordingly, the KIC firms internalised part of Océ's codification process and had to invest in creating internal codifying capabilities which were necessary to codify their tacit skills. They also learned how to communicate codified knowledge with Océ and how to use and communicate their tacit skills with their cluster partners in order jointly to create codified knowledge. In short: both Océ and its co-engineering suppliers had to learn how to organise this new 'social' division of labour, or actually this new division of the codification process.

Localisation in this case is a transformation and institutionalisation process: "institutionalisation is a kind of 'investment in forms' that reduces the costs of future transactions, such transformation costs might be conceptualized as sunk transaction costs" (Grabher \& Stark 1997: 542). KIC is a joint public/private policy aimed at embedding the externalities of the vertical disintegrated innovation process into the region, by institutionalising and localising the links between non-similar but complementary phases of the codifying process.

\section{Summary}

- Océ wanted to change it supply relationships: either go to eastern Europe to reduce costs, outsource engineering, or both;

- Suppliers wanted to reduce price competition;

- Océ had already started the KIC process with its ESI, albeit in a one on one relationship;

- Board member of the IC in Venlo was a director of Océ's R\&D department;

- IC starts by being the co-ordinator, this role is taken over by Océ;

- Problems: decreasing tendency to look for new firms to involve;

non-appearance of the teaching aspect;

conflicting CAD systems among firms;

lack of production promises;

communication between Océ's R\&D and Purchasing department;

intellectual property rights;

- The micro-clusters have shrunk and no longer include an engineering consultant: Océ felt they had little to offer and that firms had more to offer;

- The clusters have become more hierarchical;

- The KIC concept implies only loose dependence of the suppliers on the main firm;

- The concept refers to dynamic efficiency by increasing innovative and communicative capabilities of supplying firms, enhancing their role in socialising technological externalities within the region. 


\section{References}

Aoki, M. (1986) 'Horizontal Versus Vertical Information Structure of the Firm'. American Economic Review 5, pp. 971-983.

Cowan, R., D. Foray (1997) 'The Economics of Codification and the diffusion of Knowledge'. Industrial and Corporate Change, vol. 20, nr. 3, pp. 595-622.

Derix, G. (1998) Het succes van samen; verkenningen in co-development en clustering. Syntens, Venlo.

Foray, D., (1991) 'The secrets of industry are in the air: Industrial cooperation and the organizational dynamics of the innovative firm'. Research Policy 20, pp. 393-405.

Grabher, G., D. Stark (1997) 'Organising Diversity: Evolutionary Theory, Network Analysis and Post-Socialism'. Regional Studies, Vol.31.5, pp. 533-544.

Granovetter, M. (1973), 'The Stength of Weak Ties'. American Journal of Sociology, vol. 78, nr. 6, pp. 1360-1380.

Håkansson, H., (1993), 'Networks as a mechanism to develop resources'. In P. Beije, J. Groenewegen \& O. Nuys (eds.) Networking in Dutch Industries. Garant/SISWO, Apeldoorn/Leuven.

Johanson, J., L-G. Mattson (1991) 'Interorganisational relations in industrial systems: a network approach compared with the transaction-cost approach'. In G. Thompson, J. Frances, R. Levacis, J. Mitchell (eds) Markets, hierarchies and Networks: The coordination of Social Life. London: The Open University, Sage Publications.

KPMG (1996) Onderzoek naar de uitgestrektheid en samenhang van het industriële cluster 'Zuidoost-Nederland. KPMG, Amsterdam.

Louter, P.J., R.E.H.M. Smits (1997) De technologie-kaart van Nederland; Zicht op ruimtelijke verschillen in de toekomstige vraag naar afgestudeerden in de sector natuur en techniek. TNO-INRO, Delft.

Meeus, M.T.H., L.A.G. Oerlemans (1995) 'The competitiveness of firms in the region of North Brabant. An exploratory analysis of Porter's theory of competitiveness at the level of firms'. In P. Beije \& O. Nuys, The Dutch Diamond. The usefulness of Porter in analyzing small countries. Garant/SISWO, Apeldoorn/Leuven.

Ministerie voor Economische Zaken (1999) Voortgangsrapportage clusterbeleid. EZ, 'sGravenhage.

Nauwelaers, C., N. Schall and R. Wintjes (1999) SME Policy and the Regional Dimension of Innovation: The cases of Wallonia and Limburg. SMEPOL report no. 4, (EU TSER Programme). MERIT/ Maastricht University, Maastricht. 
NEI (1996) Economische betekenis van industriële kennisclusters in de regio Eindhoven/Venlo (Economic impact of industial knowledge-clusters in the Eindhoven/Venlo region). NEI, Rotterdam.

NV. REDE (1996) Synergy in Mechatronic'. N.V. REDE, economische ontwikkelings maatschappij Regio Eindhoven.

Oerlemans, L.A.G. (1996) De ingebedde onderneming: innoveren in industriële netwerken (The embedded firm: innovation in industrial networks). Tilburg University Press, Tilburg.

Polanyi, M., (1966) The Tacit Dimension. Routledge, London.

Powell, W.W. (1990), 'Neither market nor hierarchy: Network forms of organisation'. Research in Organizational Behaviour, 12, pp. 295-336.

Roelandt, Th., P. den Hartog, J. van Sinderen, B. Vollaard (1997) Cluster analysis and cluster policy in the Netherlands. Research Memorandum 9701, Ministry of Econonic Affairs, The Hague.

Storper, M., R. Salais (1997) Worlds of Production. The Action Framework of the Economy Harvard University Press, Cambridge/London.

Verspagen, B. (1998) Large Firms and Knowledge Flows in the Dutch R\&D System; A case study of Philips Electronics. MERIT- Research Memorandum. University of Maastricht, http://meritbbs.unimaas.nl/verspagen.html. 
Figure 1 Industrial knowledge-clusters in the Eindhoven-Venlo region

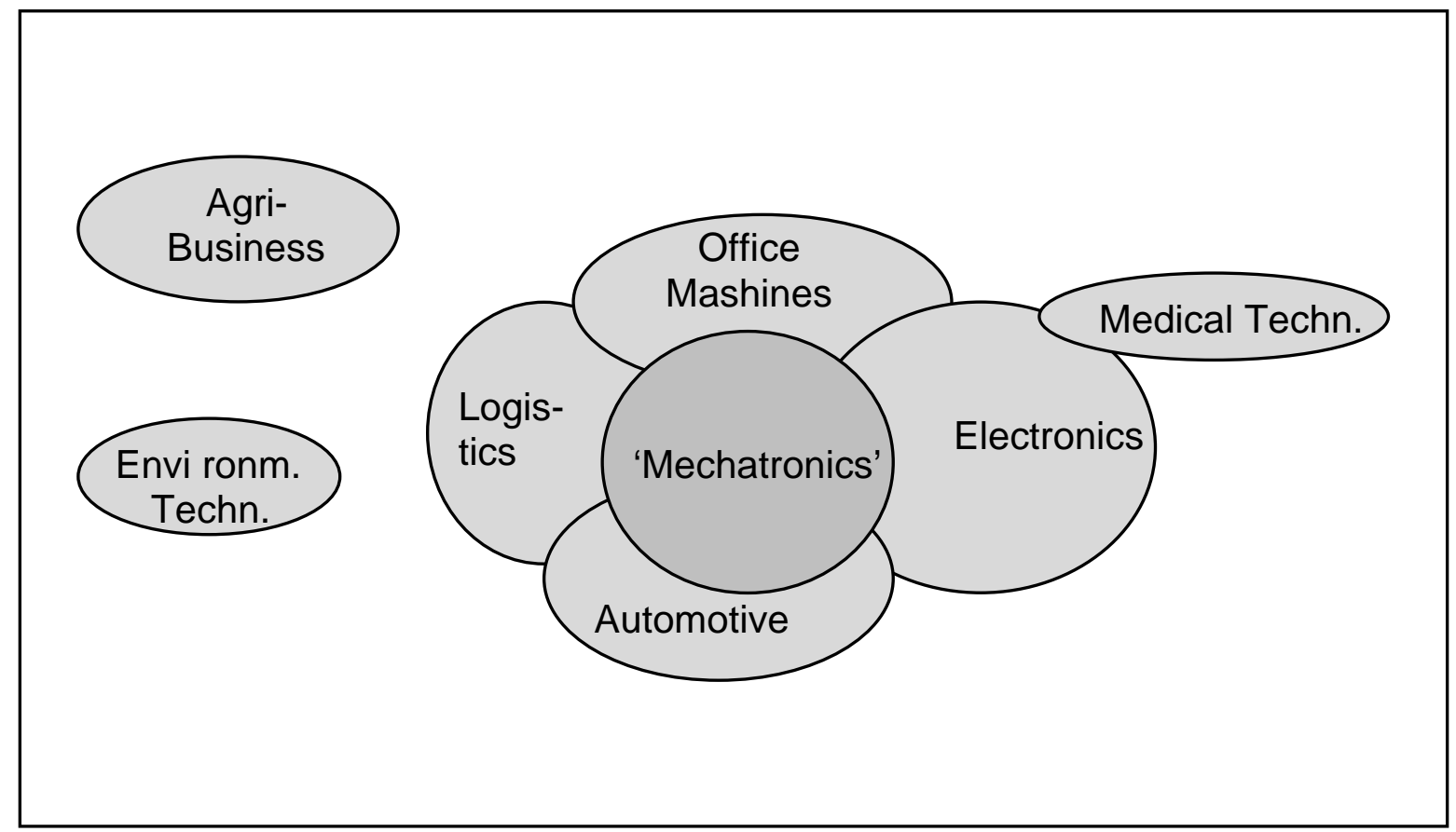


Figure 2 Discipline ratio for Research and Development at Océ in number of employees, 1980-2000

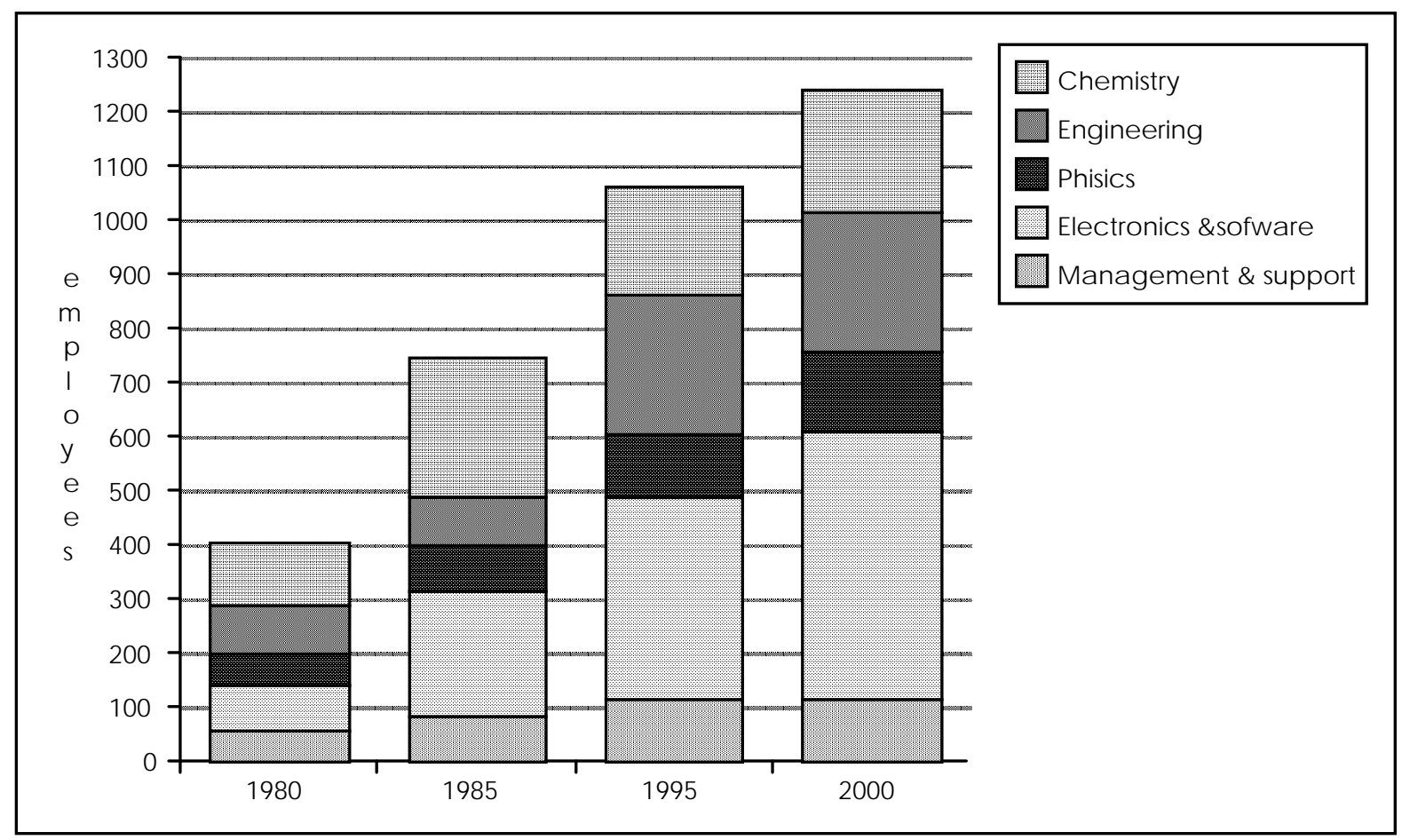

Source: Océ, 1996 
Figure 3 Origin of Océ's purchases, geographical distribution, in mln. NGL for 1988, 1993, 1996

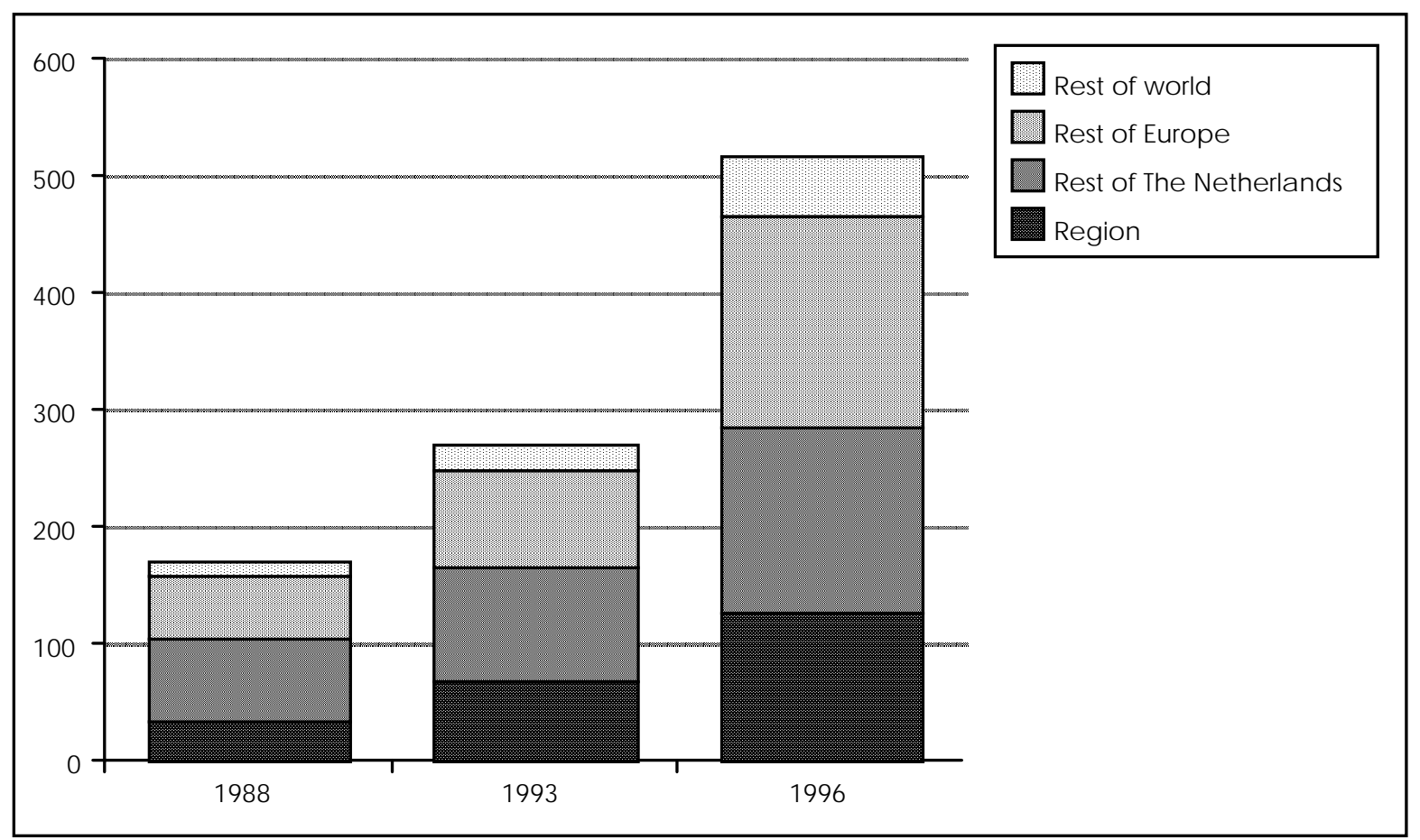

Source: Océ, 1998 
Figure 4 The position of KIC-clusters in between Océ's R\&D-unit and assembly plant

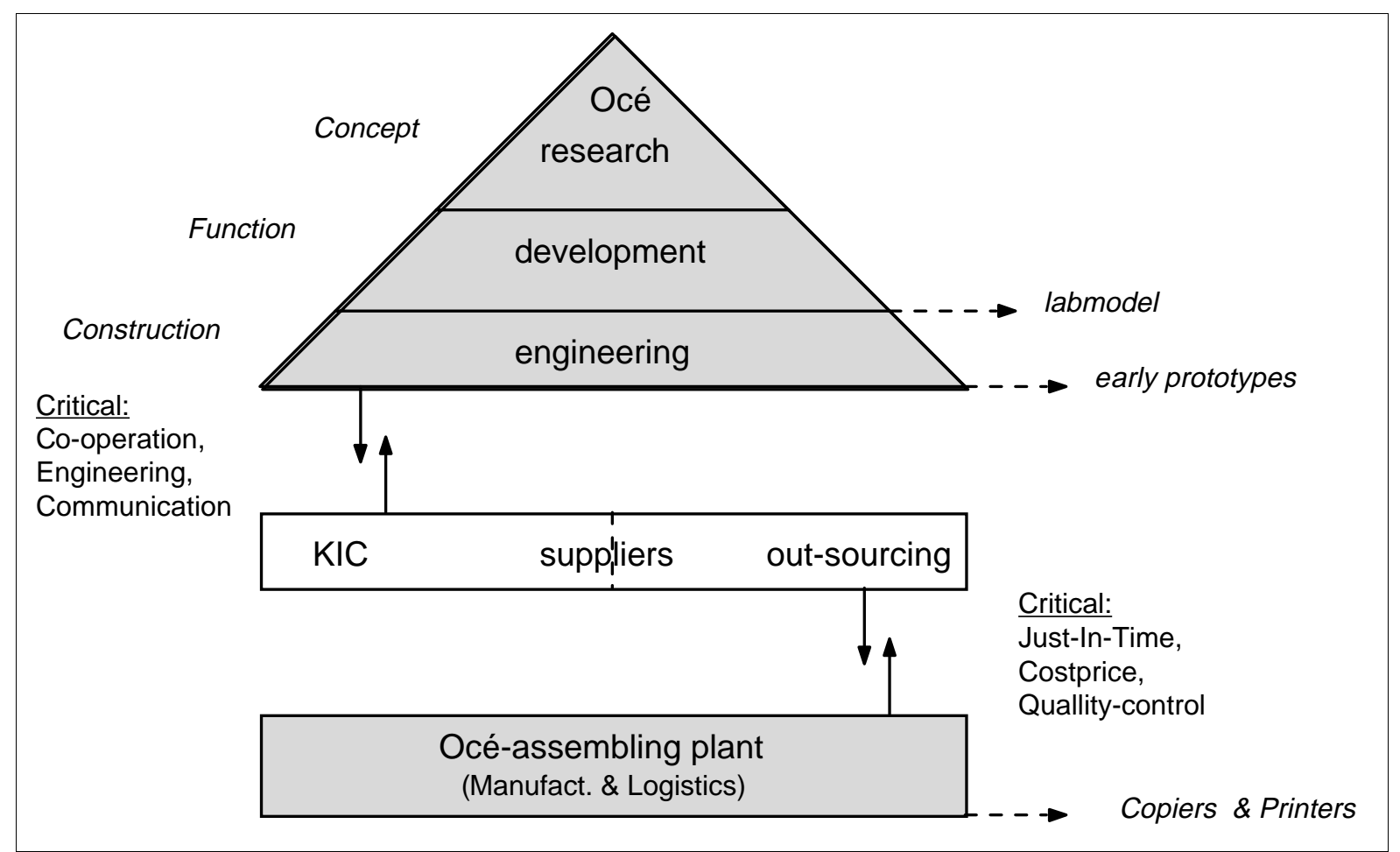


